Jurnal SOSIO DIALEKTIKA 6 (2) (2021)

p-ISSN: 2540.8941 e-ISSN: 2623.2944

e-mail; sosiodialektika@unwahas.ac.id doi; http://dx.doi.org/10.31942/sd.v6i2.5681
Pengaruh PAD Dan DAU

Terhadap Belanja Langsung (Studi Pada Kabupaten/Kota Di Provinsi Jawa Tengah)

\title{
Pengaruh PAD Dan DAU Terhadap Belanja Langsung (Studi Pada Kabupaten/Kota Di Provinsi Jawa Tengah)
}

\author{
Dhiah Novita $^{\mathbf{1}}$, Ayunda Putri Nilasari ${ }^{2}$ \\ Prodi S1 Akuntansi, Fakultas Ekonomi Universitas Tidar,Magelang, \\ Indonesia \\ dhiahnovi@gmail.com $^{1}$, ayundaputri@untidar.ac.id $^{2}$
}

\begin{abstract}
This research aims to determine the effect of local revenue and general allocation funds on direct expenditures in districts/cities of Central Java Province. The research method used is the classical assumption test, multiple linear regression analysis, and the coefficient of determination test. The results showed that partially the local original income and general allocation funds variables affected direct expenditure in districts/cities of Central Java Province. Simultaneously, the variables of local revenue and general allocation funds have an effect on direct spending in districts/cities of Central Java Province.
\end{abstract}

Keywords: direct expenditure, general allocation fund, local revenue.

\section{A. PENDAHULUAN}

Pembangunan daerah pada masa reformasi sangat krusial untuk diaplikasikan serta ditingkatkan, karena pembangunan wilayah merupakan bagian yang tidak terpisahkan dari pembangunan global, maka dari itu tidak dapat dipisahkan dengan prinsip swantantra daerah. Amanat UU supaya setiap pemerintah daerah melaksanakan pembangunan yang lebih merata dan seimbang. Daerah otonom memiliki kekuasaan dan tanggung jawab untuk melaksanakan kekrusialan warga berdasarkan prinsip partisipasi masyarakat, keterbukaan, dan tanggung jawab (akuntabilitas) (Setiyawati, 2014).

Otonomi daerah yang diberikan akan mempengaruhi perkembangan ekonomi suatu wilayah karena memungkinkan secara bebas merumuskan sendiri rencana keuangan dan merumuskan kebijakan yang mempengaruhi pembangunan daerah.. Pendapatan asli daerah diharuskan untuk selalu mendorong pertumbuhan (Rizal, 2017). Tujuannya yaitu memberikan kekuasaan kepada Pemerintah Daerah dalam menyediakan dana untuk melaksanakan kemandirian daerah berdasarkan keandalan daerah demi mewujudkan sentralisasi. (Muhtarom, 2015) menyatakan bahwa pendapatan 
Jurnal SOSIO DIALEKTIKA 6 (2) (2021)

p-ISSN: 2540.8941 e-ISSN: 2623.2944

e-mail; sosiodialektika@unwahas.ac.id doi; http://dx.doi.org/10.31942/sd.v6i2.5681
Pengaruh PAD Dan DAU

Terhadap Belanja Langsung (Studi Pada Kabupaten/Kota Di Provinsi Jawa Tengah)

asli daerah harus mendukung kapasitas fiskal suatu wilayah. PAD juga disebut sebagai penghasilan yang diperoleh suatu wilayah sesuai dengan peraturan berlaku pada suatu daerah dalam menghimpun modal bagi kegiatan di sektor yang bersangkutan (Rizanda, 2013). Menurut UU No. 33 tahun 2004, sumber PAD berasal dari: (a) retribusi dan pajak daerah; (b) hasil pengelolaan kekayaan daerah yang dipisahkan; dan (c) lain-lain PAD yang sah.. Pemerintah harus mampu meningkatkan pendapatan asli daerah yang menjadi ukuran paling utama untuk mengukur keahlian suatu wilayah supaya otonomi daerah dapat terlaksana dan terwujud (Setiyawati, 2014). Berikut merupakan data pendapatan asli daerah (PAD) Provinsi Jawa Tengah Tahun 2013-2019:

Tabel 1 PAD Provinsi Jawa Tengah Tahun 2013-2019

\begin{tabular}{cc}
\hline TAHUN & PENDAPATAN ASLI DAERAH \\
\hline 2013 & 14.303 .633 .279 .508 \\
\hline 2014 & 18.764 .753 .609 .619 \\
\hline 2015 & 20.698 .442 .504 .086 \\
\hline 2016 & 22.747 .773 .353 .248 \\
\hline 2017 & 26.945 .325 .899 .152 \\
\hline 2018 & 26.766 .784 .043 .017 \\
\hline 2019 & 28.648 .041 .587 .526
\end{tabular}

Sumber: Direktorat Jenderal Perimbangan Keuangan (DJPK)

Pada tabel 1 terlihat bahwa pendapatan asli daerah Provinsi Jawa Tengah mengalami kenaikan dan penurunan. Penurunan terlihat pada tahun 2018 yaitu Rp 26.766.784.043.017. Besarnya PAD yang didapatkan pada suatu daerah dapat meningkatkan alokasi belanja langsung. Penerimaan pajak daerah menyebabkan naik turunnya nilai pendapatan asli daerah.

Berdasar UU No. 33 Tahun 2004, dana alokasi generi merupakan modal yang diberikan oleh pusat kepada daerah bertujuan untuk mendistribusikan kapabilitas keuangan secara adil antar sektor untuk menyediakan dana bagi keperluan distrik dalam melakukan desentralisasi. DAU bertujuan dalam mewujudkan keadilan perpajakan antar pemerintah yang nilainya telah diatur serta ditransfer ke masing-masing pemerintah daerah pada saat digunakan ( $\mathrm{Ni}$ Nyoman Sri Ayu Lestari, 2018). Dana alokasi umum diberikan melalui 
Jurnal SOSIO DIALEKTIKA 6 (2) (2021)

p-ISSN: 2540.8941 e-ISSN: 2623.2944

e-mail; sosiodialektika@unwahas.ac.id doi; http://dx.doi.org/10.31942/sd.v6i2.5681
Pengaruh PAD Dan DAU

Terhadap Belanja Langsung (Studi Pada Kabupaten/Kota Di Provinsi Jawa Tengah)

penerimaan dalam negeri dalam rangka mencapai pemerataan fiskal antar daerah dan untuk memberikan dana pada keperluan belanja dalam hal melaksanakan sentralisasi yang diperoleh dari pusat (Made Ari Juniawan, 2018). Biaya didistribusikan ke provinsi (10\%) dan kabupaten/kota (90\%). DAU merupakan dana hibah yang penggunaannya tergantung pada prioritas daerah dan kepeluan dalam peningkatan layanan publik dalam melakukan swantantra wilayah.

Dalam (Permendagri No. 13 Tahun 2006) belanja langsung adalah anggaran berkaitan langsung dengan pengimplementasian rencana dan kegiatan sektor pemerintah selama periode akuntansi. Belanja langsung ditandai dengan kemampuan untuk mengukur input yang ditentukan (alokasi belanja) dan membandingkannya dengan output yang dihasilkan (Rahmat, 2016). Belanja langsung menurut jenis belanja, antara lain belanja modal, belanja pegawai, serta belanja barang dan jasa.

Pemerintah daerah dapat mengambil langkah-langkah untuk meningkatkan kemandirian daerah, mengoptimalkan potensi pendapatan berupa dana alokasi umum, pendapatan asli daerah, dana bagi hasil pajak, dan sebagainya. Karena kebutuhan untuk meningkatkan kesejahteraan masyarakat, maka pemerintah perlu mengalokasikan lebih banyak pengeluaran, dalam hal ini berkaitan kuat dengan belanja langsung, seperti pembelian barang dan jasa dalam pembangunan jalan, jembatan, dan sebagainya. Namun di Provinsi Jawa Tengah masih terjadi ketimpangan distribusi pelayanan di kota/wilayah didaerah tertinggal atau desa pelosok yang memberikan pelayanan berupa fasilitas umum, pemeliharaan (perbaikan) dan pembangunan jalan, serta daerah-daerah tersebut masih kekurangan fasilitas yang disediakan pemerintah. Sehingga PAD dan DAU berperan penting dalam mengalokasikan pengeluaran untuk mencapai kesejahteraan masyarakat. Oleh karena itu, peneliti tertarik untuk mengkaji lebih mendalam tentang antara hubungan kedua faktor tersebut dengan belanja langsung.

Berdasarkan uraian diatas, maka tujuan dari penelitian ini adalah (1) untuk memahami pengaruh pendapatan asli daerah terhadap belanja langsung di kabupaten/kota Provinsi Jawa Tengah, (2) untuk melihat pengaruh dana alokasi umum terhadap belanja langsung di kabupaten/kota Provinsi Jawa Tengah, dan (3) untuk mengetahui pengaruh pendapatan asli daerah dan dana alokasi umum terhadap belanja langsung di kabupaten/kota Provinsi Jawa 
Jurnal SOSIO DIALEKTIKA 6 (2) (2021)

p-ISSN: 2540.8941 e-ISSN: 2623.2944

e-mail; sosiodialektika@unwahas.ac.id

doi; http://dx.doi.org/10.31942/sd.v6i2.5681
Pengaruh PAD Dan DAU

Terhadap Belanja Langsung (Studi Pada Kabupaten/Kota Di Provinsi Jawa Tengah)

Tengah.

\section{B. METODE PENELITIAN}

\section{Objek Penelitian}

Objek dalam penelitian adalah pendapatan asli daerah, dana alokasi umum, dan belanja langsung pada pemerintah daerah Kabupaten/Kota Provinsi Jawa Tengah tahun 2013-2019.

\section{Populasi dan Sampel}

Populasi dan sampel dalam penelitian ini adalah Kabupaten Temanggung, Kota Surakarta, Kabupaten Semarang, Kabupaten Purworejo, Kabupaten Magelang, dan Kota Magelang. Teknik purposive sampling digunakan dalam pengambilan sampel. Alasan pemilihan sampel adalah ke enam wilayah tersebut memiliki karakteristik ekonomi yang bervariasi (berbeda-beda).

\section{Jenis dan Sumber Data}

Jenis data yang digunakan data kuantitatif yaitu data realisasi anggaran tahunan yang dipublikasikan melalui Direktorat Jenderal Perimbangan Keuangan (DJPK). Sumber data yang dipakai yaitu data sekunder yang diperoleh pada www.djpk.kemenkeu.go.id memuat data realisasi anggaran untuk data pendapatan asli daerah, dana alokasi umum, serta belanja langsung.

\section{Metode Pengumpulan Data}

Metode pengumpulan data menggunakan teknik dokumentasi.

Metode ini digunakan dengan mengumpulkan data realisasi anggaran pada tahun 2013-2019.

\section{Pengukuran Variabel}

Variabel dependen dalam penulisan ialah belanja langsung. Variabel independen yaitu pendapatan asli daerah dan dana alokasi umum.

\section{Metode Analisis Data}

(1) Uji Asumsi Klasik

(a) Uji Normalitas

Digunakan dalam membuktikan apakah varibel penggangu dalam model regresi berdistribusi normal (Ghozali, 2011). 
Jurnal SOSIO DIALEKTIKA 6 (2) (2021)

p-ISSN: 2540.8941 e-ISSN: 2623.2944

e-mail; sosiodialektika@unwahas.ac.id doi; http://dx.doi.org/10.31942/sd.v6i2.5681
Pengaruh PAD Dan DAU

Terhadap Belanja Langsung (Studi Pada Kabupaten/Kota Di Provinsi Jawa Tengah)

(b) Uji Heteroskedastisitas

Digunakan untuk memeriksa dalam sebuah regresi terjadi ketidaksesuaian varian dari residual pengamatan satu ke pangamatan lainnya. Syarat yang harus dipenuhi adalah tidak adanya gejala heteroskedatisitas (Ghozali, 2011).

(c) Uji Multikolinearitas

Digunakan untuk membuktikan ada tidaknya yang memiliki kemiripan antar variabel bebas dalam suatu model (Ghozali, 2011). Penelitian yang baik adalah tidak terdapat gejala multikolinearitas.

(d) Uji Autokorelasi

Menurut (Ghozali, 2011) tujuan autokorealasi adalah untuk menguji kolerasi antara kesalahan pengganggu pada periode tertentu dengan variabel sebelumnya.

(2) Uji Kelayakan Model

(a) Uji t

Dipakai untuk menyelidiki secara parsial pengaruh masing-masing variabel independen.

(b) Uji F

Bertujuan untuk melihat pengaruh variabel independen secara simultan (bersamaan).

(c) Uji $\mathrm{R}^{2}$ (Koefisien Determinasi)

Mengukur kemampuan model dalam menjelaskan variasi variabel independen.

(3) Analisis Regresi Linear Berganda

Digunakan untuk memprediksi seberapa besar nilai variabel akan berubah jika nilai variabel lain dilakukan manipulasi/dioperasikan (naik turun). 
Jurnal SOSIO DIALEKTIKA 6 (2) (2021)

p-ISSN: 2540.8941 e-ISSN: 2623.2944

e-mail; sosiodialektika@unwahas.ac.id doi; http://dx.doi.org/10.31942/sd.v6i2.5681
Pengaruh PAD Dan DAU

Terhadap Belanja Langsung (Studi Pada Kabupaten/Kota Di Provinsi Jawa Tengah)

\section{HASIL DAN PEMBAHASAN}

\section{Uji Asumsi Klasik}

\section{Uji Normalitas}

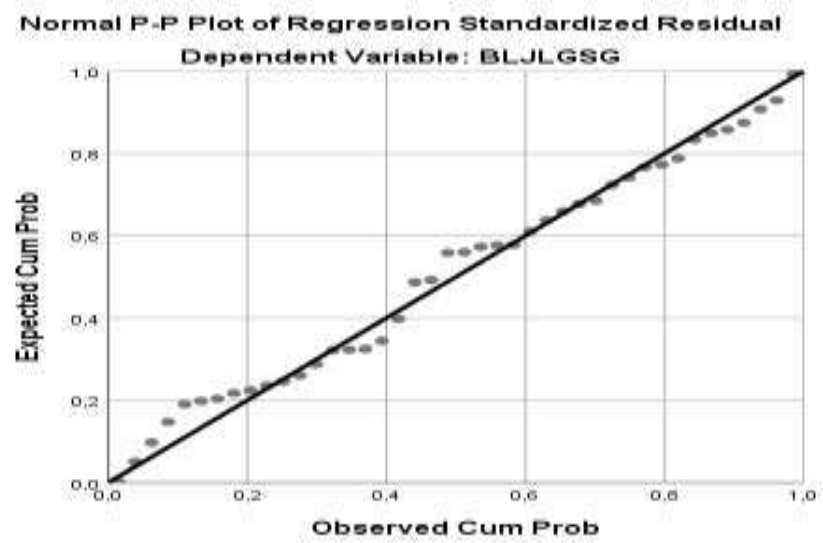

\section{Gambar 1 Grafik Normal P.P Plot}

Dari gambar 1, memperlihatkan bahwa sebaran titik menyebar diarea histogramnya. Dengan demikian dapat disimpulkan bahwa model regresi tersebut berdistribusi normal dan memenuhi uji normalitas. Untuk memperkuat hasil tersebut, dapat menggunakan uji statistik yaitu uji One Sample Kolmogrov-Smirnov.

\section{Tabel 2 Hasil Uji One Sample Kolmogrov}

One-Sample Kolmogorov-Smirnov Test

Unstandardized Residual

\begin{tabular}{|c|c|c|}
\hline \multicolumn{2}{|l|}{$\mathbf{N}$} & 42 \\
\hline \multirow{2}{*}{$\begin{array}{l}\text { Normal } \\
\text { Parameters }^{a, b}\end{array}$} & Mean & ,0000930 \\
\hline & Std. Deviation & 147221010723,89706000 \\
\hline \multirow{3}{*}{$\begin{array}{l}\text { Most Extreme } \\
\text { Differences }\end{array}$} & Absolute & ,089 \\
\hline & Positive & ,064 \\
\hline & Negative &,- 089 \\
\hline \multicolumn{2}{|l|}{ Test Statistic } & ,O89 \\
\hline \multicolumn{2}{|c|}{ Asymp. Sig. (2-tailed) } &, $2 \mathrm{OO}^{\mathrm{c}, \mathrm{d}}$ \\
\hline \multicolumn{3}{|c|}{ a. Test distribution is Normal. } \\
\hline \multicolumn{3}{|c|}{ b. Calculated from data. } \\
\hline \multicolumn{3}{|c|}{ c. Lilliefors Significance Correction. } \\
\hline
\end{tabular}

Pada tabel 2 tersebut, menunjukkan bahwa nilai KolmogrovSmirnov 0,200 >0,05. Maka dapat disimpulkan bahwa signifikasi residualnya berdistribusi normal.

\section{Uji Heteroskedastisitas}


Jurnal SOSIO DIALEKTIKA 6 (2) (2021)

p-ISSN: 2540.8941 e-ISSN: 2623.2944

e-mail; sosiodialektika@unwahas.ac.id doi; http://dx.doi.org/10.31942/sd.v6i2.5681
Pengaruh PAD Dan DAU

Terhadap Belanja Langsung (Studi Pada Kabupaten/Kota Di Provinsi Jawa Tengah)

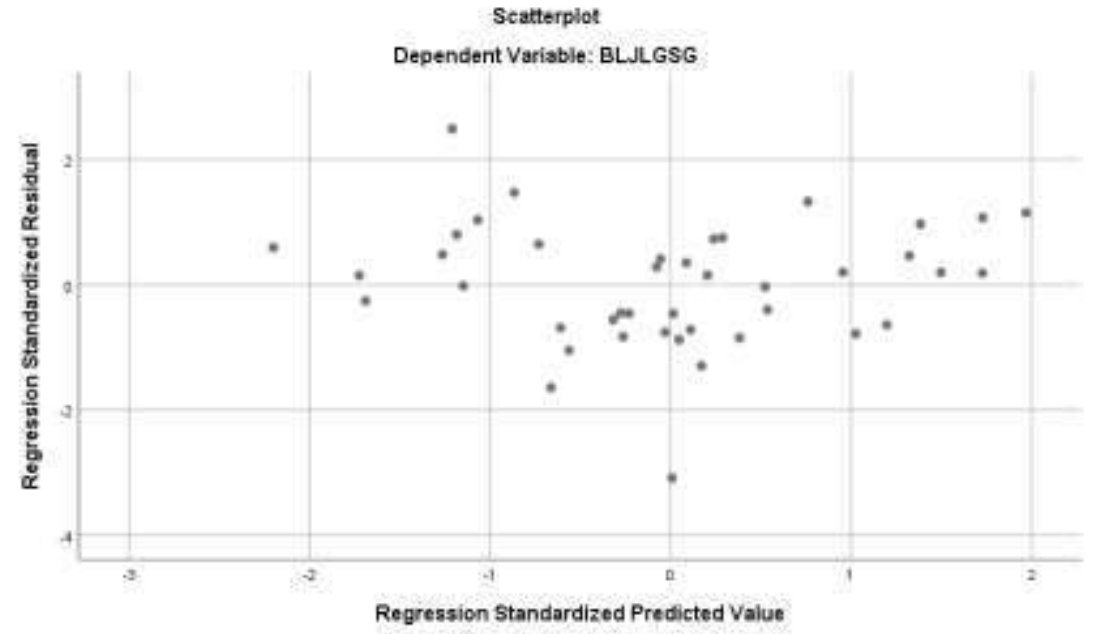

Gambar 2 Grafik Scatterplot

Berdasarkan gambar 2 terlihat bahwa sebaran titik-titik tidak membentuk suatu pola/alur tertentu, sehingga dapat dinyatakan bahwa bentuk regresi terbebas dari heteroskedastisitas

\section{Uji Multikolinearitas}

Tabel 3 Hasil Uji Multikolinearitas

\begin{tabular}{|c|c|c|c|c|c|}
\hline \multicolumn{6}{|c|}{ Coefficients $^{\mathbf{a}}$} \\
\hline \multirow{2}{*}{\multicolumn{2}{|c|}{ Model }} & \multirow[b]{2}{*}{$\mathrm{T}$} & \multirow[b]{2}{*}{ Sig. } & \multicolumn{2}{|c|}{$\begin{array}{c}\text { Collinearity } \\
\text { Statistics }\end{array}$} \\
\hline & & & & Tolerance & VIF \\
\hline \multirow[t]{3}{*}{1} & (Constant) & ,730 & , 470 & & \\
\hline & PAD & 5,933 &, 000 & ,882 & 1,134 \\
\hline & DAU & 3,208 & ,003 & 882 & 1,134 \\
\hline
\end{tabular}

a. Dependent Variable: BLJLGSG

Dari hasil pengujian pada tabel 3 tersebut, dapat diketahui bahwa nilai tolerance PAD dan DAU sebesar 0,882>0,1. Sedangkan nilai VIF PAD dan DAU sebesar $1,134<10$. Oleh karena itu dapat dikatakan bahwa model regresi terhindar dari gejala multikolinearitas. 
Jurnal SOSIO DIALEKTIKA 6 (2) (2021)

p-ISSN: 2540.8941 e-ISSN: 2623.2944

e-mail; sosiodialektika@unwahas.ac.id doi; http://dx.doi.org/10.31942/sd.v6i2.5681
Pengaruh PAD Dan DAU

Terhadap Belanja Langsung (Studi Pada Kabupaten/Kota Di Provinsi Jawa Tengah)

\section{Uji Autokorelasi}

Tabel 4 Hasil Uji Autokorelasi

\begin{tabular}{ll|r|r|r|r} 
& \multicolumn{5}{c}{ Model Summary $^{\mathbf{b}}$} \\
Model & $\mathrm{R}$ & R Square & \multicolumn{1}{c}{$\begin{array}{c}\text { Adjusted R } \\
\text { Square }\end{array}$} & $\begin{array}{l}\text { Std. Error of } \\
\text { the Estimate }\end{array}$ & $\begin{array}{c}\text { Durbin- } \\
\text { Watson }\end{array}$ \\
\hline 1 &, $794^{\mathrm{a}}$ &, 630 &, 611 & 15094871483 & 1,739 \\
& & & & 8,22840 & \\
\hline
\end{tabular}

a. Predictors: (Constant), DAU, PAD

b. Dependent Variable: BLJLGSG

Pada tabel 4, terlihat nilai Durbin-Watson 1,739 yang kemudian akan dibandingkan dengan nilai tabel yang diperoleh dari nilai signifikasi 5\% jumlah sampel 42 (n) dan jumlah variabel bebas $2(\mathrm{k}=2)$. Hasil tabel hitung DW untuk $\mathrm{dL}=1,4073$ dan $\mathrm{dU}=1,6061$ serta poin 4dU sebesar 2,3939. Hasil tersebut dapat juga dinotasikan dengan dU < DW < 4-dU. Hal tersebut berarti bentuk regresi terlepas dari masalah autokorelasi.

\section{Uji Kelayakan Model}

Uji t (Parsial)

Tabel 5 Hasil Uji t (Parsial)

\begin{tabular}{|c|c|c|c|c|c|}
\hline \multicolumn{6}{|c|}{ Coefficients $^{\mathrm{a}}$} \\
\hline \multirow{2}{*}{\multicolumn{2}{|c|}{ Model }} & \multirow[b]{2}{*}{$\mathrm{T}$} & \multirow[b]{2}{*}{ Sig. } & \multicolumn{2}{|c|}{$\begin{array}{c}\text { Collinearity } \\
\text { Statistics }\end{array}$} \\
\hline & & & & Tolerance & VIF \\
\hline \multirow[t]{3}{*}{1} & (Constant) &, 730 &, 470 & & \\
\hline & PAD & 5,933 & ,000 & ,882 & 1,134 \\
\hline & DAU & 3,208 &, 003 &, 882 & 1,134 \\
\hline
\end{tabular}

a. Dependent Variable: BLJLGSG

Berdasarkan hasil pengujian pada tabel 5 diatas dapat diketahui sebagai berikut:

(1) Hubungan antara pendapatan asli daerah dengan belanja langsung Hasil uji $\mathrm{t}$ pada tabel 5 menunjukkan bahwa tingkat signifikasi variabel pendapatan asli daerah senilai $0,000<0,05$ 
Jurnal SOSIO DIALEKTIKA 6 (2) (2021)

p-ISSN: 2540.8941 e-ISSN: 2623.2944

e-mail; sosiodialektika@unwahas.ac.id doi; http://dx.doi.org/10.31942/sd.v6i2.5681
Pengaruh PAD Dan DAU

Terhadap Belanja Langsung (Studi Pada Kabupaten/Kota Di Provinsi Jawa Tengah)

yang artinya $\mathrm{H}_{1}$ diterima atau dengan kata lain variabel PAD secara signifikan berdampak terhadap belanja langsung. Hasil penelitian sejalan dengan (Rahmat, 2016) dan (Rizal, 2017) bahwa pendapatan asli daerah (PAD) berpengaruh terhadap anggaran belanja modal. Hasil yang sama juga dilakukan oleh (Setiyawati, 2014) yang menyatakan bahwa pendapatan asli daerah (PAD) berpengaruh siginifikan pada belanja langsung.

(2) Hubungan antara dana alokasi umum dengan belanja langsung

Tabel 5 menunjukkan bahwa tingkat signifikasi variabel dana alokasi umum senilai $0,003<0,05$ yang artinya $\mathrm{H}_{2}$ diterima atau dengan kata lain variabel dana alokasi umum secara signifikan berpengaruh terhadap belanja langsung. Hasil penelitian sejalan dengan yang dilakukan (Rahmat, 2016), (Ni Nyoman Sri Ayu Lestari, 2018), dan (Setiyawati, 2014) yang menghasilkan dana alokasi umum berpengaruh secara signifikan terhadap belanja langsung. Penelitian yang dilakukan (Rizanda, 2013) menyampaikan bahwa dana alokasi umum (DAU) berpengaruh positif dengan belanja modal.

\section{Uji F (Simultan)}

\section{Tabel 6 Hasil Uji F}

\begin{tabular}{lr|r|r|r|r}
\multicolumn{7}{c}{ ANOVA $^{\text {a }}$} & & \\
Model & Sum of Squares & Df & Mean Square & F & Sig. \\
\hline Regression & 151430735114285 & 2 & 757153675571425 & 33,230 &, $000^{\mathrm{b}}$ \\
& 1600000000,000 & & 800000000,000 & & \\
\hline Residual & 888635065941198 & 39 & 227855145113127 & & \\
& 900000000,000 & & 90000000,000 & & \\
\hline Total & 240294241708405 & 41 & & & \\
\hline & 0600000000,000 & & & & \\
\hline a. Dependent Variable: BLJLGSG & & \\
b. Predictors: (Constant), DAU, PAD & &
\end{tabular}

Berdasarkan tabel 6 dapat diketahui bahwa tingkat signifikasi sebesar $0,000<0,05$ yang berarti bahwa $\mathrm{H}_{3}$ diterima atau dengan kata 
Jurnal SOSIO DIALEKTIKA 6 (2) (2021)

p-ISSN: 2540.8941 e-ISSN: 2623.2944

e-mail; sosiodialektika@unwahas.ac.id doi; http://dx.doi.org/10.31942/sd.v6i2.5681
Pengaruh PAD Dan DAU

Terhadap Belanja Langsung (Studi Pada Kabupaten/Kota Di

Provinsi Jawa Tengah)

lain kedua variabel berpengaruh simultan pada belanja langsung.

\section{Uji $\mathbf{R}^{2}$ (Koefisien Determinasi)}

Tabel 7 Hasil Uji Koefisien Determinasi

\begin{tabular}{ll|r|r|r|r} 
& \multicolumn{9}{c}{$\begin{array}{c}\text { Model Summary } \\
\text { Model }\end{array}$} & R & R Square & \multicolumn{1}{c}{$\begin{array}{c}\text { Adjusted R } \\
\text { Square }\end{array}$} & $\begin{array}{l}\text { Std. Error of } \\
\text { the Estimate }\end{array}$ & $\begin{array}{l}\text { Durbin- } \\
\text { Watson }\end{array}$ \\
\hline 1 &, $794^{\mathrm{a}}$ &, 630 &, 611 & 15094871483 & 1,739 \\
& & & & 8,22840 & \\
\hline
\end{tabular}

a. Predictors: (Constant), DAU, PAD

b. Dependent Variable: BLJLGSG

Tabel 7 menunjukkan nilai $\mathrm{R}^{2}$ sebesar 0,630 , hal ini berarti sebesar $63 \%$ belanja langsung dipengaruhi oleh pendapatan asli daerah dan dana alokasi umum. Sisanya 37\% dipengaruhi oleh variabel lain yang tidak terdapat pada model regresi.

\section{Analisis Regresi Linear Berganda}

Tabel 8 Hasil Uji Regresi Linear Berganda

\section{Coefficients $^{\mathrm{a}}$}

\begin{tabular}{lc|r|r|r|r} 
& \multicolumn{2}{c|}{$\begin{array}{l}\text { Unstandardized } \\
\text { Coefficients }\end{array}$} & $\begin{array}{c}\text { Standardized } \\
\text { Coefficients }\end{array}$ & & \\
Model & \multicolumn{1}{c|}{ B } & Std. Error & Beta & \multicolumn{1}{c|}{ T } & Sig. \\
\hline 1 (Constant) & 74528839 & 102163557 & &, 730 &, 470 \\
& 043,620 & 377,432 & & & \\
\hline PAD & 1,379 &, 232 &, 615 & 5,933 &, 000 \\
\hline DAU &, 399 &, 124 &, 333 & 3,208 &, 003 \\
\hline
\end{tabular}

a. Dependent Variable: BLJLGSG

Berdasarkan tabel 8 maka diperoleh model persamaan regresi:

$$
Y=74528839043,620+1,379 X_{1}+0,399 X_{2}+e
$$

Model persamaan regresi diatas dapat diuraikan sebagai berikut:

(a) Nilai konstanta sebesar 74528839043,620 berarti apabila variabel PAD dan DAU bernilai nol, maka belanja langsung sebesar 74528839043,620 .

(b) Variabel PAD berpengaruh terhadap belanja langsung dengan nilai sebesar 1,379. Maka setiap terjadi penambahan variabel pendapatan asli 
Jurnal SOSIO DIALEKTIKA 6 (2) (2021)

p-ISSN: 2540.8941 e-ISSN: 2623.2944

e-mail; sosiodialektika@unwahas.ac.id doi; http://dx.doi.org/10.31942/sd.v6i2.5681
Pengaruh PAD Dan DAU

Terhadap Belanja Langsung (Studi Pada Kabupaten/Kota Di Provinsi Jawa Tengah)

daerah (PAD) sebesar satu satuan, maka belanja langsung juga akan meningkat senilai 1,379 .

(c) Variabel DAU berpengaruh signifikan terhadap belanja langsung senilai 0,399. Maka setiap penambahan variabel DAU senilai satu satuan, maka belanja langsung akan meningkat sebesar 0,399.

\section{SIMPULAN}

Dari hasil riset yang dilaksanakan yang menggunakan analisis regresi linear berganda tentang pengaruh pendapatan asli daerah (PAD) dan dana alokasi umum (DAU) terhadap belanja langsung di Kabupaten/Kota Provinsi Jawa Tengah tahun 2013-2019, dapat disimpulkan sebagai berikut:

(1) Pendapatan asli daerah dan dana alokasi umum secara parsial berpengaruh terhadap belanja langsung di Kabupaten/Kota Provinsi Jawa Tengah.

(2) Belanja langsung di Kabupaten/Kota Provinsi Jawa Tengah secara simultan dipengaruhi oleh pendapatan asli daerah dan dana alokasi umum.

(3) Hasil uji $\mathrm{R}^{2}$ sebesar 0,630 atau $63 \%$ variabel belanja langsung dipengaruhi oleh pendapatan asli daerah dan dana alokasi umum. Sisanya dipengaruhi oleh variabel lain yang tidak teliti dalam penelitian ini yaitu sebesar $37 \%$.

\section{DAFTAR PUSTAKA}

Christia, A M., Ispriyarso, B., Studi , P. Ilmu, M, Hukum, F, \& Diponegoro, U. (2019). Desentralisasi fiskal dan otonomi daerah di indonesia. 15.

Ghozali, I. (2011). Aplikasi Analisis Multivariate dengan Progam SPSS. Badan Penerbit Universitas Diponegoro.

Iqbal , M. (2012). Pengolahan Data dengan Regresi Linier Berganda. Perbanas Institute Jakarta, 4, 1985-2000.

Jambi, K., Ariansyah, M., Amir, A., \& Achmad, E. (2014). Tingkat Ketergantungan Fiskal dan Hubungannya dengan Pertumbuhan Ekonomi di Kota Jambi M.Ariansyah, Amri Amir, Erni Achmad I(3), 159-164. 
Jurnal SOSIO DIALEKTIKA 6 (2) (2021)

p-ISSN: 2540.8941 e-ISSN: 2623.2944

e-mail; sosiodialektika@unwahas.ac.id doi; http://dx.doi.org/10.31942/sd.v6i2.5681
Pengaruh PAD Dan DAU

Terhadap Belanja Langsung (Studi Pada Kabupaten/Kota Di Provinsi Jawa Tengah)

Made Ari Juniawan, N.P.S. S. (2018). PENGARUH PAD, DAU DAN DAK TERHADAP BELANJA MODAL Fakultas Ekonomi dan Bisnis Universitas Udayana, Bali Indonesia 7(3), 1255-1281.

Muhtarom, A. (2015). Junal EKBIS/Vol. XIII/No.1/edisi Maret 2015 |659. XIII(1), 659_667

Ni Nyoman Sri Ayu Lestari, I. W. B. (2018). Pengaruh Anggaran Pendapatan

Belanja Negara (Apbn) Terhadap Belanja Langsung Pada Pemerintah Daerah Kabupaten/Kota. 4(1), 24-33.

Nihayah, A. Z. (2019). Pengolahan Data Penelitian Menggunakan Software SPSS 23.0. UIN Walisongo Semarang, 1-37.

Permendagri. (2006). Permendagri No.1 3/2006. 1-73.

Rahm at, A. (2016). Pengaruh PAD, DAU Dan DAK Terhadap Belanja Langsung Nur Handayani Sekolah Tinggi Ilmu Ekonomi Indonesia (STTESIA ) Surabaya Rizal. Y. (2017). Pengaruh Pendapatan Asli Daerah, Dana Alokasi Umum dan Dana Alokasi Khusus Terhadap Alokasi Belanja Modal Daerah

Kota Langsa. Jurnal Samudra Ekonomi Dan Bisnis, 8(1), 634-645. https://doi.org/10.33059/jseb.v\&il.203

Rizanda, P. (2013). Pengaruh Pendapatan Asli Daerah Dan Dana Alokasi Umum Terhadap Belanja Modal Di Provinsi Jawa Timur. Jurnal Akuntansi Unesa, $1(2), 1-28$

Setiyawati, N. H. \& H. (2014). Pengaruh Dana Alokasi Umum, Dana Alokasi

Khusus Dan Pendapatan Asli Daerah Terhadap Belanja Langsung Di

Propinsi Jawa Tengah, Nurul Hidayah \& Hari Setiyawati. XVIII (01), 4558.

Setyadhama Andryan. (2010). Ujian Kompre. 0-10.

Undang-Undang Republik Indonesia Nomor 33 Tahun 2004 Tentang Perimbangan Keuangan. (2004). 